Creating Order in the absence of Formal Regulations and Law: a Historical perspective on Corporate Governance and the Joint Stock Company

\author{
Dr. Damian Tobin
}

Centre for Finance and Management Studies

School of Oriental and African Studies

Thornhaugh St. | Russell Square

London | WC1H OXG

tel +44 (0)20 78984058

email: $\underline{\mathrm{dt} 29 @ \text { soas.ac.uk }}$ 


\title{
Creating Order in the absence of Formal Regulations and Law: a Historical perspective on Corporate Governance and the Joint Stock Company
}

\begin{abstract}
The legal and political explanations that underpin the contemporary literature on corporate governance have focused how the prevailing political or legal system determines how large corporations are governed. They imply that in order to facilitate good corporate practices, emerging economies should converge towards governance systems that offer strong legal protection for investors. Distinguishing itself from this approach, this paper adopts a historical account of the major political economy factors that either impeded or facilitated the evolution of the Anglo American Joint Stock Company (JSC). This illustrates how the JSC did not emerge by blueprint or design as is implied in the literature. It also describes the implicit costs associated with the JSC including political rent seeking, the expropriation of small investors, market crises and monopolies. Under these circumstances legal and political developments often enhanced corporate power at the expense of the public interest. This account suggests that the JSC is better viewed as an adaptive and innovative organisational form that has thrived in the absence of formal regulations and law, rather than as a nexus of contracts arising from market failure. The evolution of the JSC and its corporate governance structures are therefore best understood within a political economy framework that accounts for market developments, political and legal interventions and the rise of the regulatory state. For developing economies the main lesson is not that they should replicate either the US or UK, but rather they can draw on the factors that allowed both countries to lessen the costs of mobilising finance, and adapt them to suit local market structures.
\end{abstract}




\section{Introduction}

The dominant legal and political explanations that underpin the contemporary literature on corporate governance and the emergence of the joint stock company (JSC) have focused on the relationship between corporate governance and domestic institutions, in particular on how the legal system determines how large corporations are governed (LLSV, 2000; Levine, 1999). It implies that in order to facilitate capital market development, emerging economies should converge towards governance systems that offer strong legal protection for investors. Others have approached the issue from a political perspective, arguing that it is the political system not the law that determines governance structures (Roe, 2000; Bebchuk, 1999). Yet, economic history illustrates how legal and political developments often enhanced corporate power at the expense of the public interest. Adam Smith (1776) was one of the first to point out how forming a JSC with limited liability effectively exempted its directors from public accountability. The exemption from trouble and risk, except for the sum invested, proved a huge incentive for investors with little knowledge to invest. Writing in a similar vein in the aftermath of the 1929 Wall St. crash, Berle and Means (1932) agued that the logical outcome of the modern corporation was ownership of wealth without control and control without appreciable ownership. These warnings appear almost as relevant in the aftermath of the recent corporate scandals, as they did to the emerging system of finance in $19^{\text {th }}$ century Europe. Existing perspectives on the corporation therefore present an interesting question, namely 'how, in the absence formal regulations and law typically thought to underpin its existence, should the evolution of the JSC be viewed, and how these lessons should be applied in developing economies?'

In addressing this question, this paper distinguishes itself from the dominant legal and political perspectives on the firm by focusing on the evolution of the Anglo American JSC with limited liability from a historical perspective. The paper argues that the historical ability of the JSC to eclipse many of the obstacles to its development underscores its adaptive nature. It argues that these adaptive qualities are much better understood in terms of political economy, by focusing on how legal and political institutions have both facilitated and limited the growth of the JSC. Drawing on the approach of Coffee (2001) who questioned the link between legal origin and governance structure, this paper highlights two major features of the JSC. The first is that the Anglo-American JSC did not emerge by blueprint or design. In reviewing the developments that facilitated ownership to shift from family ownership/sole proprietor to the market, the emergence of the Anglo-American system of governance was characterised by such factors as learning from international financial techniques, self- 
regulation and the use of financial intermediaries. The second is that there exists an implicit cost to the JSC. In The Wealth of Nations, often regarded as the cornerstone of laissez-faire, Adam Smith pointed out the many defects that characterised the development of the JSC. These included political rent seeking, a high degree of state influence, the expropriation of minority investors, and the huge inefficiencies of monopolies. These events cast doubt upon the thesis that the US corporate form, with its strong managers and dispersed shareholders is a "path dependent" political artefact (Cheffins, 2000). Instead they point toward an adaptive form of organisation, which although influenced by legal and political systems, has also thrived in their absence.

The historical perspective applied in this paper suggests that the relationship between corporate governance and the systems of legal protection and corporate regulation governing the JSC are more complex in origin. It describes how development of the JSC occurred largely in the absence of formal codes and regulations. Long before investor protection and regulatory standards reached the thresholds that are now deemed necessary for market development, active capital markets and competitive markets for goods and services were well established. Where formal legal protection or political interventions did emerge, their effect was often to legitimise existing, and sometimes corrupt, corporate practices. As such the formal protection of property rights was not necessarily a pre-condition for forms of economic organisation such as the JSC. Instead the early development of the JSC was characterised by unorthodox and adaptive structures, which sought to mitigate the costs associated with weak property rights and exploit the absence of enforceable laws and regulations. In this manner, corporations themselves became instrumental in shaping the "rules of the game". Although the rules of the game have become more sophisticated and the channels of political influence become more standardised, it is also true that the modern corporation has become more adaptive, incorporating in the most regulatory attractive jurisdictions, diversifying ownership and further shifting the boundaries of the traditional firm (e.g. Zingales, 2000). This further underscores the need for a move away from viewing the firm as a nexus of contracts, towards one that accounts for how the firm evolves and adapts over time.

In questioning the idea that the emergence of the Anglo Saxon JSC is related to specific legal or political systems, section two establishes the very different origins that characterised its development in both the UK and US. Section three explores the evolution of the JSC in the UK. It describes how the first JSCs adopted various unorthodox structures to mitigate governance problems. Early financial market development in the UK was dominated by state securities; a factor that was crucial to fostering confidence in what was then a developing 
market. In the absence of developed managerial structures and legal protection, family ownership often represented the best protection for private firms. Section four describes how in the US, self-regulation was an important feature of the early development of the New York Stock Exchange (NYSE) where financial intermediaries used their reputation to lower the transaction costs of mobilising capital. Section five evaluates the implications of the historical perspective for the theory of the firm and for emerging economies. It concludes that for developing economies the implication is not that they should replicate either the US or UK as is implied by the legal and political perspectives, but rather they should draw on the factors that allowed both countries to lessen the costs of mobilising finance, even when the prevailing legal and political environments appeared to be prohibitive.

\section{Distinctive Patterns of Development}

To begin with it is clear that the Anglo-American JSC have very different starting points that were related to country specific features. The variety in development patterns of both the US and UK makes it difficult to generalise. In the $19^{\text {th }}$ century Britain followed a policy of reducing the restrictions on trade while the US adopted protectionism. British companies were able to rely on internal financing for much of their early development and as a first mover in the industrial revolution its industry faced less competitive pressures. American companies had to rely to a greater extent on external finance and faced a much tougher competitive environment. Confidence in the public debt provided British investors with a much higher level of trust in securities markets at an early stage. American investors relied much more on the reputation of financial intermediaries.

\section{Very Different Starting Points}

Gerschenkron (1962) distinguishes between three types of countries in terms of their ability to mobilise capital. The first category referred to "advanced" countries with lots of private wealth that could be easily mobilised to finance enterprise growth. Britain during the $17^{\text {th }}$ and $18^{\text {th }}$ centuries would have undoubtedly fitted this category. The second category referred to "moderately backward" countries that had less wealth to draw upon, but had enough to finance industry, provided a system of finance was put in place to mobilise private wealth. The third category referred to "very backward" countries where private wealth and resources were insufficient and state intervention was necessary to mobilise capital. America, at the beginning of the $19^{\text {th }}$ century, probably fell somewhere between the second and third categories. 
For the UK, economic history tends to paint a picture of highly innovative and risk taking entrepreneurs exploiting new opportunities. Yet much of the increases in production in the early industrial revolution appear to have been driven by inventions inherited from the Power Revolution of the middle ages. ${ }^{1}$ In most instances, it was the general movement of the economy that dictated change, not technical innovations per se (Lilley, 1976). Important technical innovations did take place, but only when the economic conditions were ripe. ${ }^{2}$ The emphasis was on deep (revolution) rather than fast (Landes, 1999). The technological advances of the industrial revolution did not take place over night. ${ }^{3}$ Britain became the 'workshop of the world' not necessarily through innovation, but rather because of their ability to apply monopolistic positions to profitably exploit the home market (Chambers, 1961). Manufacturers faced a favourable market for mass-produced moderately priced goods. Intense competition, where it existed, did not adversely affect large manufacturers as surplus production could be exported. ${ }^{4}$ Rising living standards and an expanding export market meant that making money did not require a huge degree of management skill. Alfred Marshall (1920) observed that rich old firms could survive on mere momentum, even if they lost the resourcefulness that was the original source of their success. The simplicity of production processes and the modest investment demands of many industries meant that firms could expand through building more units, with continued control by the proprietor, without having to adopt the joint-stock structure. ${ }^{5}$ As a consequence, there was little pressure to initiate corporate restructuring.

In the case of America, factors such as its industrial history, the course of economic change and geography, affected its ability to mobilise capital and distinguished it from the UK (Davis, 1966). The geographical distance from wealthy European investors made the cost of capital more expensive (Coffee, 2001). America had also just emerged from a costly civil war (18611865), one of the consequences of which was a large national debt (Sylla, 1967). It faced the tasks of putting in place a system of public infrastructure, almost two centuries after the

\footnotetext{
${ }^{1}$ Rapid growth occured in such industries as cotton, even before major technical innovations (Lilley, 1976).

${ }^{2}$ Lilley (1976) cites the cases of the pioneering inventions of Hargreaves (the "Spinning Jenny" 1798), Arkwrignt (the "Water Frame" 1769) and Crompton (the "Mule" 1779). Although these led to an explosive growth in the cotton industry, their invention followed two to three decades after the first acceleration of growth in the industry. They did however allow expansion to rise to a rate not previously possible.

${ }^{3}$ Landes (1999) cites the example of steam power. The first device using steam to create a vacuum was patented in England in 1698. Sixty years later, after various adaptations of steam technology, an engine with a separate steam condenser and efficient enough to be used outside mining was invented. It took another fifteen years before this was suitable for driving the wheel of industry and so on.

${ }^{4}$ Lethal competition did not greatly affect the cotton spinning trade until 1830. See Payne (1978: 188).

${ }^{5}$ Pollard (1964) notes that even in the early cotton mills, coalmines, and iron furnaces, fixed capital was relatively simple and cheap. As such transformation did not require installing costly machinery.
} 
chartered joint stock company was used for a similar purpose in Britain. As a consequence, much of the early development of securities markets in the US was driven by the huge capital demands of the railroads (Coffee, 2001). ${ }^{6}$ This was later replicated by similar demands for capital from such other sectors as steel, automobile and telephone. One of the problems for American industry in the $19^{\text {th }}$ century was that it had to deal with a variety of changes in scale, technology and location in a much shorter timescale than the UK. Davis (1966) argues that in the UK, much of the growth at this time took place through the expansion of industries that were already in existence. On the other hand, towards the end of the $19^{\text {th }}$ century the US experienced the rapid growth of such industries as petroleum and iron, industries which it had no experience of prior to 1850 .

\section{The End of the Complete Businessman}

The Industrial Revolution in the UK is typically associated with the gradual transition from workshop to factory production that occurred in the $18^{\text {th }}$ and $19^{\text {th }}$ centuries. From a corporate governance perspective what is significant about the industrial revolution is that it signalled the decline of the "complete businessman" as the owner and manager of large business. The rise of the multi-partnership and later the joint-stock company in economic activity witnessed a delegation of the proprietor's managerial role to a team of businessmen (often family) who were responsible for making strategic decisions and running the enterprise (Payne, 1978). This change in the structure of enterprises was accompanied by a shift in how enterprises were to be financed. Proprietors no longer expected to finance their activities solely from such traditional sources as personal and family wealth, or borrowings based on reputation. Payne (1978) observes two functional splits that occurred at this time, which are relevant to governance arrangements. The first is the emergence of the capitalist as a separate enterprise function. The second concerns the split between those who made strategic decisions and those who kept the concern running. Those who made strategic decisions could still be classed as entrepreneurs, while those who kept the concern running can be considered managers.

The functional changes in organisation were accompanied by the emergence of corporate governance problems. Marshall (1920) highlighted the problems facing second and third generation of owners, many of who were brought up to believe that life was easy. These were content to let the enterprise be run by salaried assistants. Enterprises continued to be

\footnotetext{
${ }^{6}$ The scale of capital required by the railways is most evident from a comparison with the canal companies. Between 1815 and 1860 the canals received US\$ 188 million in investment, 73 percent of which was supplied by the state and local government. By 1859 , US $\$ 1,100$ million had already been invested in the debt securities of private railroad companies, most of which was invested in the period 1849-1859 (Chandler, 1977: 90).
} 
profitable, not least because of the general inflation of prices. Payne (1978) observes the decline of certain industries in the mid-1800 citing some examples of poor management practices, failure to adapt, quality control problems, and declining productivity. Some firms maintained their positions as a result of inelastic demand for their products, however Payne suggests that many more would have failed had they been subject to greater competition. Landes (1965) is similarly critical in noting that while some owners were wise enough to leave the running of the enterprise to professional management, others went through the motions of entrepreneurship.

The result was an arrangement that was at best a poor substitute for interested ownership. While the move towards the joint stock company listed on the stock exchange was well underway by the end of the $19^{\text {th }}$ century, the move towards the professional management structures associated with the modern corporation was much slower to develop (Cheffins, 2000). Some owners retired and their firms were converted into joint stock companies. This brought with it its own problems. Family considerations often determined the selection of management (Landes, 1965). When more of these firms started to join the stock market, there was a tendency for the founding entrepreneurs and their heirs to maintain considerable ownership stakes, and thereby also retain a significant role in the middle and top-level management decision-making (Cheffins, 2000).

\section{Competitive Pressures}

The pace of development in American industry meant that enterprises faced much greater competitive pressures than their UK counterparts from the Industrial Revolution. Competition resulted in a quicker adoption of hierarchical organisational structures. The growth of the multi-unit firm based on administrative coordination, allowed the faster delivery of larger quantities of goods to consumers (Chandler, 1977). Competition in such capital-intensive industries as the railroads, telecoms and steel resulted in a demand for large amounts of investment. ${ }^{7}$ This capital had to come from European investors. The demand for international capital and the inherent risk for investors investing in a developing market produced two basic innovations that sought to maximise the reputation value of new stock issuances (Coffee, 2001). The first was a corporate governance system with a strong role for financial intermediaries. These originally served the function of protecting investors, and later took

\footnotetext{
${ }^{7}$ Ramirez (1995) cites the example of the telephone company AT\&T, which in the early 1900s began to lose its status as a monopoly power, as more and more companies entered the industry. To improve its efficiency and maintain services, the company was forced to raise additional capital.
} 
seats on the board of directors to monitor management and protect against predatory raiders attempting to take control by stealth. The second innovation was the growth of self-regulation through stock exchange rules.

\section{Reluctance to Change}

While both the US and UK experienced varying degrees of competitive pressures at the early stages to their development, what is similar in both cases is the reluctance to separate ownership and control. Although the need to mobilise finance is often cited as a reason for adopting the joint stock company, a much greater constraint on enterprises emerging from the Industrial Revolution in the UK, appears to have been a lack of management structures and the general difficulties associated with industrial organisation in the development context. ${ }^{8}$ This is not to suggest that major fixed investment did not take place or that small enterprises did not find it difficult to access capital. Fixed investments in the period can be divided into two groups: those that were made in public utilities which swallowed up the largest portion of fixed investment, and those that made in private manufacturing (Pollard, 1964). However, in the absence of a significant finance constraint, unifying ownership and management was an effective method of mitigating the level of risk faced by the enterprise. In the US, competitive pressures acted as a similar constraint. Chandler (1977: 489) notes that concentration and oligopoly emerged in response to rapid growth, to improve firm security through limiting the entrance of new competitors. Complex tasks required greater administrative coordination, while competition created incentives to merge into larger structures.

Even though there appeared to be a trend towards adopting the corporate form with professional management as the Industrial Revolution progressed, there remained reluctance on behalf of businesses to adopt the joint stock format. Payne (1978) notes a general reluctance on behalf of business enterprises to make radical changes in company structure. Company law in the area was seen as giving the appearance of change while in fact maintaining continuity. ${ }^{9}$ Even where limited liability joint stock companies were formed, ownership and control typically remained in the hands of a small few.

Up until the end of the $19^{\text {th }}$ century, family was the dominant form of ownership of American industrial enterprise. Belcher (1904) observed a general preference for

\footnotetext{
${ }^{8}$ See Thompson's (1967) historical account of the social and cultural issues, which led to highly irregular working patterns during the early Industrial Revolution.

9 A number of "really public" companies were initially registered under the companies codifying Act of 1862. However a large and increasing proportion of companies registered were noted to be private with a small number of members, some of whom were dummies. See Payne (1978, pages 203-304).
} 
manufacturers at the time towards owning their own plants. Intense competition had the effect of lowering the rents available to controlling block holders. American corporations responded to increasingly competitive domestic market conditions by adopting cartel-like structures. Consolidation was regarded as a suitable remedy to the problems of ruinous competition, the cost of which would have had to be recouped through higher prices (Belcher, 1904). The strength of the trend towards a consolidated corporate structure was evident in the response to the Sherman Antitrust Act of 1890. The basic thrust of the Act was to outlaw price fixing and collusion among competitors. Its effect was to result in a great wave of corporate mergers between 1895 and 1903. Instead of engaging in cartels, large firms engaged in monopoly forming mergers.

\section{From Family to the Market}

From about the 1880s onwards the initial reluctance to adopt the joint stock company appears to have been cast aside. Payne (1978) points to the significant build up of pressures by the 1840s in the UK economy that threatened the long standing dominance of the noncorporate enterprise. They included the increasing size of enterprises, the finance requirements necessitated by the exploitation of new techniques and the inappropriateness of the partnership form of organisation to supply this type of finance. The law of partnership had evolved in such a manner, as to make every partner liable for the losses of the enterprise (Payne, 1978). This liability extended down to their last acre and schilling. Understandably, few were willing to take this risk, as the demands for capital grew. Cheffins (2000) provides a number reasons explaining why the JSC emerged on a significant scale in the last quarter of 1800s and the early 1900s. These concerned the marked decline in lending to foreign borrowers; the shift in assets away from government securities and land; the demand for an exit option by families that had built up firms during the industrial revolution; and the demand for capital to finance expansion, the scale of which was too large for traditional sources. The stock market allowed English industry to draw on the vast wealth of the gentry and nobility (Gille, 1976).

In the US, the wave of mergers and the anti-trust law that preceded it were crucial to the eventual emergence of the widely held corporation. Two organisational innovations were generally adopted as a response to market competition (Chandler, 1977). The first involved a horizontal fusion of assets of competing companies. The second involved the formation of holding companies, which exercised tight managerial control over subsidiary companies. These saw the emergence of hierarchical management structures, with professional managers, independent from enterprise owners. It also sped up the process of transferring ownership to 
the market. For proprietors of firms, which disappeared in mergers, the logical step was to unwind their holdings (Cheffins, 2002). This was a process in which they engaged in reluctantly. The expectation was that "direct management by a manufacturing owner may be expected to be more efficient than management by distant financiers representing stockholders" (Belcher, 1904: 121-122). In this manner, although change did not occur immediately, control of American corporations made the transition from family to market. By the time Berle and Means (1932) conducted their survey on the separation of ownership and control in American corporations, the trend towards dispersed ownership was well established.

\section{The Separation of Ownership and Control in the UK}

It is difficult to identify exactly when the separation of ownership and control occurred in the U.K. While the process began early in the industrial revolution, it is fair to say that it did not gain widespread acceptance until the latter half of the $20^{\text {th }}$ century. ${ }^{10}$ This indicates that the emergence of what we now know as the widely held corporation was a product of almost three centuries of evolution. Central factors in this evolution included the emergence of London as a financial centre and its ability to apply international financial techniques and the development of the London Stock Exchange (LSE). What is significant is that this development was characterised by financial crises, corrupt practices and the influence of corporate interest on the political system. Moreover there existed very limited legal protection of investors or the public interest. While the laws governing incorporation ensured a high standard of disclosure, they often had the effect of institutionalising the control of directors at the expense of minority shareholders and the public. Yet, despite these problems the long-term effect was to strengthen rather than weaken public confidence in the joint stock company. In response to corrupt practices a political consensus gradually emerged that sought to ensure the JSC operated in the public interest.

\section{Learning from Abroad}

London was not always the dominant financial centre of Europe. At the end of the 1600s, Amsterdam dominated Europe's financial market. It had already developed large markets in securities, commodities and foreign exchange, and its stock market was the busiest and most technologically advanced in the world (Schubert, 1988). Schubert (1988) identifies three

\footnotetext{
${ }^{10}$ In 1936, the median proportion of voting shares held by the 20 largest shareholders in the 82 largest nonfinancial UK corporations was approximately 40 percent. Similar data for 1977 showed that the 20 largest shareholders held between 20 and 29 percent of voting stock. Source Coffee (2001: 40).
} 
significant catalysts in the emergence of London as a financial centre. The first concerns the taking control by parliament, of funding the national debt. This improved the standing of England as a borrower. The national debt enabled parliament to borrow from the public pool of savings, but it also bound investors in national debt to the stability of the regime (Hoppit, 1986). The second concerns the importation of Dutch techniques of finance by William III. The techniques used by William to raise credit were in fact very similar to those he had employed in the Netherlands, the difference being the location (Neal, 1987). The third deals with the founding of the Bank of England in 1694 thereby providing the London market with a more credible and stable source of credit. According to Schubert (1988:300) these modernisations "gave London the opportunity to develop into a major financial centre on a par with Amsterdam."

A crucial element of the financial practices that William brought to England was the resale of shares in joint stock corporations (Neal, 1987). This was effectively the modern stock exchange. Although Neal (1987) notes that chartered JSCs existed in England prior to William's arrival, trades in their shares and the numbers of such companies increased considerably in the 1690s. To aid him in his purpose, William brought with him from the Netherlands numerous financial advisors "who were eager to apply in a relatively backward England, the financial techniques and institutions that had been developed over the past century in Amsterdam" (Neal, 1987:98). Their activities resulted in the founding of such wellknown banks and companies as the Bank of England, the New East India Company (1698), the United East India Company (1702) and the South Sea Company (1711). They were traded on both the London and Amsterdam markets.

Despite the fact that the LSE was mainly a market for government securities, it had little difficulty in attracting large numbers of investors. Even in the lead up to the collapse of the South Sea Bubble, and despite the scepticism of some leading members of parliament, the sceptics "were a small minority compared with the huge number of investors who at least until the summer of 1720, crowded Exchange Alley from dawn to dusk and made fortunes by investing in anything from the smallest bubble to shares of the monied companies" (Harris, 1994: 619). The confidence attached to the government's debt conversion scheme meant that even when the South Sea Bubble Act was introduced in 1720 to control speculation, the immediate reaction of investors was not panic.

\section{Corrupt Politicians and the Joint Stock Company}

The bursting of the South Sea Bubble in 1720 and subsequent revelation of improper political practices provided the setting for the eventual separation of politics and business. Of 
particular significance was the passing in 1720 of the South Sea Bubble Act. The commonly held view is that the act was a response to the bursting of a speculative bubble (bull market), or as a legislative response to the abuse of investors (Patterson and Reiffen, 1990). The sequence of events suggests that neither was the case. The Bubble Act was passed in June 1720; the South Sea Bubble burst in September 1720. Stock in the South Sea Company continued to increase in value after the passing of the act and did not collapse for another two months. ${ }^{11}$ Patterson and Reiffen (1990) present a convincing argument that the bubble act was specifically intended to prevent non-chartered firms from using the formal market, an objective that it achieved quite brilliantly. Similarly, Harris (1994) argues that the Bubble Act had all the characteristics of a piece of special interest legislation. In this regard Harris favours an explanation based on the South Sea Company itself initiating the act, "because it believed that the wave of small bubbles competed with the company's conversion scheme" (Harris, 1994: 612).

The Bubble Act had important implications for the development of financial markets and the JSC. Prior to the 1720 bubble, public confidence in the stability of the regime had grown. The uncertainty surrounding the public finance system introduced by William into the UK gave way to certainty (Hoppit, 1986). This confidence did not grow unchecked and crises were an inevitable feature of market growth. However it was not a catastrophe. The bursting of the bubble represented the ending of a period of speculative momentum. The wider consequences of the ending of speculative bubble were less pronounced, with the greatest sufferers being the inexperienced investors who sold too late (Hoppit, 1986). More significant was the Bubble Act's effect on the system of finance. The act helped to ensure that the speculative element in the formation of non-state companies was kept to a minimum (Hoppit, 1986).

Financial implications aside, the South Sea Bubble had important political repercussions. Those who opposed the Bubble Act on the grounds that it encouraged speculative trading found themselves isolated in terms of strong South Sea interests who had no objection so seeing the companies stock become a bubble (Harris, 1994). However the financial chaos following the collapse of the bubble and the public reaction to the revelations of the corrupt political involvement provided a catalyst for the fusing together of disparate opposition movements in parliament (Jones, 1993). This resulted in a backlash against perceived corrupt business practices leading to what Jones (1993) describes as transparent efforts by the

\footnotetext{
${ }^{11}$ Sock in the South Sea Company was priced at $£ 750$ in early June 1720 after the passing of the Bubble Act, almost five times its price in January 1920. The shares peaked at $£ 1050$ on the $24^{\text {th }}$ of June before beginning their decline in August. By the end of September they had collapsed to £300. Source: Harris (1994: 613).
} 
responsible ministry to "save their skins" and prosecute the directors of the South Sea Company. These events indicate that even when the JSC was still largely a state entity, it had already gained considerable corporate power and influence over the political system. Only after the emergence of financial crises and the revelation of corrupt practices did a credible political check on the JSC operation emergence.

\section{Financial Crises and Political Retreat}

The collapse of the South Sea Bubble can be viewed as one of a series of crisis to hit the development of the UK's stock markets in the 1700s. Hoppit (1986:44) lists no less than 13 possible years between 1700 and 1800 where a financial crisis could be considered to have occurred. In the aftermath of the South Sea Bubble, the LSE remained essentially a market for government securities. Even as late as 1840 , only 11 percent of the securities traded on the LSE were not issued by the government, and even these tended to be attributable to such quasi government organisations as the East India Company, South Sea Company and the Bank of England (Michie, 1987). Yet the $19^{\text {th }}$ century also witnessed the emergence of the LSE as a preferred market for securities, despite the dominance of the state. The Bubble Act was unexpectedly repealed in 1825 . Government issues were increasingly replaced by corporate stocks and bonds and the LSE began to attract international listings from the US and France (Michie, 1987).

The period after 1720 witnessed the end of the spontaneous incorporation of joint stock companies and a return to strict government controls over the granting of joint stock charters. As a consequence many enterprises were forced to adopt less formal financing structures that were not unlike those witnessed in the early period of the industrial revolution. These included "family firms, closed partnerships, or unincorporated companies of doubtful legality" (Harris, 1997: 675). In any event the 1720 act proved difficult to enforce, with only one instance in the $18^{\text {th }}$ century where a persecution occurred (Harris, 1994). Capital hungry entrepreneurs routinely disregarded restrictions on the formation of JSCs. Large numbers of JSCs in existence were not incorporated by the state, either by royal charter or special act of parliament. $^{12}$ In addition a speculative bubble emerged during the early 1820 s, which was partly driven by the floating of loans by Latin American countries. These were followed by Latin American mining companies whose promises of riches were well received on the

\footnotetext{
${ }^{12}$ In the early 1820s before the repeal of the Bubble Act, Harris (1997: 577) notes that there were 150 joint stock companies in England, many of which were not incorporated in accordance with the 1720 act.
} 
London market. The result was an increase in the numbers of companies seeking special acts to allow them form joint stock companies.

The first political reaction was that the speculative frenzy would eventually run it course. JSCs could form if they wished so long as they did not interfere with parliament. ${ }^{13}$ Companies that went to parliament seeking legislative approval for listings were subject to much lobbying between the public and private interest. ${ }^{14}$ Consequently during the period 1824-1825, Harris (1997:687) notes, "a considerable number of members of parliament were manipulating for, or being manipulated by, powerful private interest groups." This situation eventually proved unworkable and in 1825 the initial bubble act was repealed on the basis that its legal implications were unclear. Moreover it was acknowledged that many of the unincorporated companies served a useful purpose and were in the public benefit. Interestingly, the repeal of the Bubble Act was followed in 1826 by a crash in stock market values and a run on the banking system. By 1827, only 15 of 624 companies formed between 1824 and 1825 traded above their paid up price, and almost 500 had disappeared altogether (Harris, 1997: 692).

What is significant is that despite the existence of the JSC since early in the Industrial Revolution, legislation regulating their free formation did not come into being until 1844. In the mean time, they existed both in a formal manner for chartered companies and an informal manner for those who did or would not have succeeded in getting a charter of special act of parliament. The repeal of the Bubble Act can therefore be interpreted as critical in the emergence of the JSC as it signalled an end to political inference in the granting of charters and the beginning of a more impartial style of corporate regulation. Although a general incorporation act did not come into being until 1862, there was little doubt that by the latter half of the $19^{\text {th }}$ century, a reasonably active market for industrial securities existed (Davis, 1966).

\section{The Emergence of the Dispersed Ownership with Limited Liability}

The corporate governance practices of larger British corporations towards the end of the 1800s were still a long way from the "best practice" that we expect of the modern corporation. The Joint Stock Companies Act, enacted in 1856, put in place the legislative framework governing the modern corporation with limited liability. Yet it is clear the JSC enjoyed all the

\footnotetext{
${ }^{13}$ At the time, parliament was much more concerned with such issues as food supply (Harris, 1997).

${ }^{14}$ On such case was that of the new Liverpool and Manchester Railway Line. Its promoters and bankers, as well as those in other parts of the kingdom who would have benefited from the line's construction supported the line. Two major interest groups opposed the company: shareholders of canals that already served the route and landowners concerned with land value and the land expropriation power of the company. Parliamentarians were lobbied and lobbied on behalf of these various interests. See Harris (1997: 685).
} 
benefits of the JSC structure with limited liability long before this date. The 1856 Act at most resulted in technical changes in the details of ownership, but control did not shift from the founding entrepreneurs and families. Cheffins (2000) argues that Family control remained a complicating factor right up to the mid $20^{\text {th }}$ century. The boards of directors were still enjoyed considerable discretion in the governance of their companies (Payne, 1978). Indeed consistent with Adam Smith's concerns on the freedoms attached to the JSC structure one director remarked to the 1886 Committee on Trade and Industry, that "it has been an advantage to my Company to be a Limited Liability Company - because I have as much power as a director of this company as I had as a partner and the resources of this company are greater than the resources of the old partnership." 15 Even in the early 1900s, the rights of minority shareholders were still subject to the ability of larger shareholders to ratify any conflict of interest transaction, thereby placing it beyond judicial review (Coffee, 2001). Despite these limitations investors were increasingly investing in shares and diversifying their holdings across different companies. This indicates that at the time, trust in the system was more important than the lack of specific legislation protecting minority shareholders. Coffee (2001) argues that such factors as a strong normative code or perceived exposure to loss of reputation may have restrained UK managers in the absence of law. Such trust had been a long-term feature of market development in the UK.

Similar to previous legislative reforms in the $17^{\text {th }}$ and $18^{\text {th }}$ centuries, the legal protection of shareholders' rights only emerged as a response to crisis. As such its emergence can neither be regarded as intended nor planned. In the aftermath of a series of stock market scandals in the 1870s, parliament overruled a judicial decision in 1890 that narrowly construed the meaning of fraud by enacting the Directors Liability Act of 1890 (Coffee, 2001). This allowed investors to recover damages if (1) they suffered loss through misleading claims in the issuing prospectus, and (2) those responsible could not prove that they had reasonable grounds to believe the statement was true (Coffee. 2001:42). This was followed by numerous pieces of legislation, each leading towards mandatory disclosure, which culminated in 1929 with legislation that required companies to disclose an income statement and other data on earnings. A similar change was also evident in the listing procedures of the LSE. Up to the early 1900s the LSE had been content to adopt a laissez-faire approach to the companies that it listed. However, Coffee (2001) notes that following another speculative boom in new issues during the 1920s, a major scandal hit the LSE in 1929. This forced the LSE to tighten its listing

\footnotetext{
${ }^{15}$ See Payne, 1978: 204.
} 
requirements and place a greater focus more on the quality of the shares it listed. In effect it had taken the first steps towards self-regulation.

\section{Institutional Innovations and the Emergence of the US Corporation}

An important difference between the financial centres of London and New York at the end of the $19^{\text {th }}$ century was the level of investor confidence. What London had, New York lacked. The NYSE was located far from the wealthy European investors. America was then a developing nation and as such, investors would have had good reason to be cautious. Such practices as price manipulation by controlling block-holders, judicial corruption, asset stripping, and arbitrary regulatory enforcement were rife in America's securities markets in the late $19^{\text {th }}$ century. Even the legislative protection afforded to shareholders could be nullified through bribery and judicial corruption. Similar to how legislation in the UK often had the effect of strengthening the hand of corporations and their directors, instead of being used to protect minority shareholders the US legal system was used as a method for legitimising corrupt practices. ${ }^{16}$ Seligman (1983) notes the prevalence of "watered stock" during the period between 1897 and 1910, where 79 cases in all were identified. Promoters would buy up competing plants and sell to the public stock, which exceeded the value against which the stock was issued. In this manner, the agency problem that emerged in America was somewhat different to that which emerged in the first joint stock companies in the UK. Instead of fear of expropriation by management, US investors were more exposed to expropriation by incoming controlling shareholders (Coffee: 2001). How the NYSE overcame such constraints to become the "guardian of investors" is therefore highly significant to developing economies seeking finance abroad. Towards the end of the $19^{\text {th }}$ century European investors were quite willing to purchase the stocks of US companies, particularly railways that were listed on such major international markets as London, Paris or Amsterdam. ${ }^{17}$ For these companies the combination of efficiency and liquidity made London particularly attractive. The question was therefore how to give the investors confidence in the NYSE? Two innovations were crucial to this. The first was the use of financial intermediaries such as J.P. Morgan. The second was the selfregulatory role adopted by the NYSE.

\section{The J.P. Morgan Effect}

\footnotetext{
${ }^{16}$ Coffee (2001:27-28) provides a concise account of these problems for shareholders in Erie Railroad.

17 The Atchison, Topeka and Santa Fe Railroad Company issued 4 percent mortgage bonds on the Amsterdam and London Stock Exchange in 1896. 22.7 percent of the bonds were issued in Amsterdam, 29.5 percent in London and the remainder on the NYSE (Mitchie 1987).
} 
From the mid-1800s, US investment banks played an important intermediary function between American companies and European investors. J.P. Morgan, an American investment banker, found that in the poorly organised markets of the US substantial profits could be made by securing finance for large well-known domestic companies (Davis, 1966). Consequently it was in the interests of companies to form close ties with investment banks. In return, investment banks took seats on the boards of these companies. The relationship was not an arm's length one. "Informal ties and quid-pro-quo types of obligations abounded" (Ramirez, 1995: 661). Having a representative of J.P. Morgan sitting on the board of directors, added approximately thirty percent to the value of the company's ordinary stock (De Long, 1991). For minority shareholders, the presence of a reputable investment bank also lessened the transparency problems. It achieved this by resolving the information and incentive problems between shareholders and management by having the investment bank act as an intermediary (Ramirez, 1995).

A second and related feature of financial intermediaries was the way in which they assisted the transfer of control from families to market. Financial intermediaries such as investment banks took a leading role in the wave of industry consolidation that occurred towards the end of the $19^{\text {th }}$ century. In the first instance their role provided investor confidence in the new corporations. A second crucial role played by financial intermediaries was the way in which they helped overcome owners' reluctance to offload their holdings. Where leadership was lacking or conflict existed, promoters took a leading role and retained a block of shares as consideration (Cheffins, 2002).

\section{The NYSE and Self-Regulation}

The emergence of the NYSE was also significant in overcoming the information problems faced by potential foreign investors. "From well before 1900, the NYSE saw itself as the guardian of the financial quality of the issuers listed on it" (Coffee, 2001:37). Later this became evident in a number of ways including its preference for low risk companies, and its decision, albeit reluctantly, to refuse to list non-voting shares in the 1920s. On the other hand, as noted earlier, the LSE tended to adopt a more laissez-faire approach to the companies it listed. The difference in approaches may have much to do with America's position as a late starter and the much more competitive environment under which the NYSE operated.

At the end of the $19^{\text {th }}$ century the NYSE was not the main stock market in the US. The first canal companies tended to raise finance in their own states. The capital demands of the railroads changed this. Private railroad operators were the first companies to raise capital 
outside of their own states (Chandler, 1977). This worked to the advantage of New York. Similar to London in the $18^{\text {th }}$ and $19^{\text {th }}$ centuries, railway bond issuers gravitated towards New York from the $1850 \mathrm{~s}$, because it was the only financial centre that could supply the scale of finance necessary. ${ }^{18}$ As a result the American capital market became institutionalised in New York (Chandler, 1977). Although it may have dominated the market for debt securities, it ranked well behind other exchanges in terms of the trading of equities. However, unlike other exchanges, it did not attempt to compete for business based on low commissions or by luring as many new issuers as possible. Instead it competed on quality. Consequently its focus was on the needs of the "substantial investor" (Coffee, 2001: 36).

One issue highlighted by Coffee (2001) referred to how the NYSE dealt with the problem of non-voting shares. Prior to the beginning of the 1900s, there existed little restriction on the voting rights of shareholders (Stevens, 1926). Both common and preference stock in railroad companies appeared to have full voting rights. However Stevens (1926) noted an increasing trend towards restricting of the voting rights of certain classes of shareholders. This was accompanied by a move towards concentrated voting control. The response of the NYSE was to adopt a policy of refusing to list non-voting common stock. This was followed by regulations that prevented listed companies from issuing a block of stock of sufficient size to transfer control, without first seeking the approval of shareholders. The issue has particular significance given the findings of Classens et al (2000) that the separation of residual and voting rights was one of the main forms of minority shareholder expropriation that occurred in Asia during the 1990s.

The proactive self-regulatory approach adopted by the NYSE allowed it to distinguish itself from its competitors. By presenting itself as a reputable exchange, it was able to establish the trust of investors and issuers. Long before the Securities Acts of 1933 and 1934 introduced mandatory disclosure, the NYSE already had in place a strict set of listing requirements. It is doubtful that this was put in place solely for the public good. Coffee (2001) argues that there was an element of self-interest in the NYSE's exclusive listing criteria. Its ability to turn away companies with poor trading histories helped distinguish it in terms of quality from other exchanges.

\footnotetext{
${ }^{18}$ As capital became scarcer in Boston, many issuers increasingly turned to New York where capital was less scarce and money rates were lower (Chandler, 1977).
} 


\section{Distinctive Patterns of Development: Implications for Theory and Practice}

The sequence of these events described in this paper, along with recent developments, indicate that the legal and political explanations need to be put in the context of the economic history before their implications for developing economies and the theory of the firm can be fully assessed. The JSC with limited liability has undoubtedly prospered from what Adam Smith described as an exemption from trouble and risk, except for the sum invested. It has also benefited from adaptive and innovative qualities, which have to a large degree allowed it to prosper in the absence of formal regulatory and legal enforcement. This is not to lessen the significant of legal and political developments. Various regulatory actions by both the UK and US governments were crucial in standardising the relationship between political and business interests at various stages in history. More recently the Sarbanes-Oxley Act of 2002 mandated much corporate governance including the structure of boardroom committees (Roe, 2005). This created what has arguably been one of the most stringent set of corporate regulations in history, and emerged to protect the integrity of US financial markets in the aftermath of serious corporate scandals at both Enron and WorldCom. In accounting for these developments, this section argues that the evolution of the JSC and its corporate governance structures are best understood within a political economy framework that accounts for effects of market developments, political and legal interventions and the rise of the regulatory state on the JSC. It also briefly assesses these implications for the theory of the firm and developing economies.

\section{A Political Economy Perspective on the Evolution of the JSC}

The implications of this paper are consistent with recent political economy approaches to market development (e.g. Pagano and Volpin, 2001; Rajan and Zingales, 2003), which emphasise how incumbents can either impede or facilitate market growth. The evolution of the JSC illustrates how the extent to which legal and political institutions have been able to both limit and facilitate the powerful corporate interest groups has to a large degree affected the extent to which JSCs are accountable for their actions. The political economy perspective also captures the important role of the state. In the UK, the actions of the government were crucial at various stages in removing the obstacles to development. In the US, where the state has traditionally taken a lesser role in economic activity and where individual states enjoy a high degree of discretion in corporate law making, Roe (2005) points out that in almost every decade of the $20^{\text {th }}$ century the major corporate issue either went or threatened to go federal. Indeed Rajan and Zingales (2003) argue that it is the state that possesses the ability to 
coordinate standards and aid enforcement; hence if action is necessary the political desire to carry out this is crucial. It is therefore crucial to understand the rise of the state's role as a regulator of the JSC and how this role has evolved over time.

Probably of most significance is the fact that in each instance, developments in the market tended to be legitimised by legal and political developments, rather than the other way around. The political power and lobbying of the South Sea Company in 1720 prompted the Bubble Act, making it one of the first examples of special interest legislation. Its repeal only came about, over a century later when the act was no longer economically and politically practical. The 1856 Joint Stock Companies Act, which put in place the legislative framework for limited liability, in many respects enhanced the corporate power of private co-partneries. The overall effect of corporate laws such as the 1862 Companies Codifying Act was to give the impression of change, when in fact none occurred.

In the early $19^{\text {th }}$ century, politicians in the UK gained considerable rents for lobbying for charters on behalf of enterprises. In the US, judges and politicians could be bribed, with the effect of legitimising corrupt practices. Compulsory disclosure was not legislated for until the consistent failure of issuing prospectuses to disclose material investment risks were identified by Congress as a factor in the losses suffered by investors in the late $1920 \mathrm{~s} .{ }^{19}$ Similarly, the rise of holding companies and trusts, which used vast pyramiding structures to concentrate control, was not legislated against until after the Wall Street Crash in 1929. The demand for public utility regulation, in particular that of the railroads, only emerged after a large number of railroad companies collapsed and went into receivership (Dillion, 1925). Even in anti-trust, the decision to break up monopolists often followed events that had already been decided in the market place. In the case of Standard Oil, Pratt (1980) notes that historical accounts of developments in America's oil industry suggest that the Supreme Court merely accelerated an ongoing economic process.

The emergence of a political commitment to laissez faire in the UK also appears to have significantly benefited the JSC. This commitment did not emerge spontaneously, but rather in response to specific economic and political developments. Fay (1948) argues that the important reforms at the time tended to follow the pattern of reform and repeal. One example is that of the Royal Charter which granted the Crown the sole right to grant JSC status. The Statute of Monopolies in 1623 reversed this situation by stating that all monopolies, however

${ }^{19}$ Prior to the Securities Acts of 1933 and 1934, US investors purchased large quantities of foreign bonds, particularly from Latin America. The collapse of the world economy in the late 1920s led to a substantial depreciation of these bonds. A Senate Finance Committee identified significant disclosure problems, particularly their failure to state material investment risks. Seligman (1983: 24-27). 
they were granted, were void (Patterson and Reiffen, 1990). Similarly the repeal of the 1720 Bubble Act, largely removed the Crown's control over the incorporation of the JSC. Such political reforms went hand-in-hand with a shift in the balance of power from state to market. What is significant in the move towards laissez faire is that although mercantile interests initially predominated, Lilley (1976) notes that industry was given the room to manoeuvre, allowing it to eventually take the major share of political power. Britain's approach was in stark contrast to the continent where the government supported the development of large industry as a direct extension of mercantilist practices (Gille, 1976). Although other European nations imported the Industrial Revolution, they did not on the whole adopt the official (or lack of official) policy (Supple, 1976). One could therefore argue that the political power of the JSC was therefore enhanced by the legislative repeals associated with laissez faire.

The above is not to diminish the important political and legal reforms that did occur. Britain pursued a policy of the "continued dismantling of the structural, fiscal, and economic barriers to the mobility of men and resources" (Supple, 1976: 320). The repeal of the Corn Laws in 1846 is cited as one of the most known examples of innovative decisions making by political agents designed to curb the power of elites and remove the barriers to free trade (Lusztig, 1995). Its effect was that the political hegemony could no longer exercise control over both policy and economic activity. Similarly, the tolerance of corruption gradually became incompatible with economic development. This did not occur immediately. The repeal of the Bubble Act was in part due to the sheer unsustainable nature of political corruption.

How then do we interpret the role of legal and political institutions from the historical perspective? In the first instance it is clear that business interests played a significant role in shaping corporate norms, but that these were later codified in law. Clay and Wright (2005) describe how self-regulatory mining codes provided a peaceful solution to property rights disputes during the Californian Gold Rush in the absence of federal mining laws. However they point out that these codes are best understood as institutions for managing access to resources whose location is uncertain, rather than as enforcers of property rights. Similarly Coffee (2001:66) argues that while financial markets developed in the absence of a strong mandatory legal framework "they neither function optionally nor develop to their potential in the absence of mandatory law that seeks to mitigate the risks of crashes". In this regard, a more plausible explanation is that the cost of influencing justice did not increase as fast as the size of business as argued by Glaeser and Shleifer (2003). The rise of the regulatory state therefore occurred at the backdrop of the failure of private litigation to adequately protect individuals in the market place. 


\section{Implications for Firm Theory}

Taking the shareholder as the principal supplier of capital to the firm, many seminal contributions to the literature on corporate governance have focused on how the supplier of equity can limit the discretionary behaviour of management through market contracting. This market-based paradigm views the firm as a nexus of contracts. Its central focus is on the separation of ownership and control. An example is the legal approach, which has sought to investigate the relationship between the legal protection of investors and ownership structure. The concern with ownership has its origins in the fears expressed by Adam Smith (1776) and Berle and Means (1932) that the emergence of the widely held corporation created opportunities for the appropriation of investors' wealth. The search for new paradigms has been underpinned by the recognition that investor ownership does not necessarily dominate other ownership forms (Hansman, 1996), and that the boundaries of the traditional firm have shifted (Zingales, 2000). The emerging dominance of institutional investors, the widespread nature of employee ownership, the increasing popularity of employee stock ownership, producer-owned cooperatives in the agricultural sector and the prevalence of state ownership all challenge the conventional assumption of the supremacy of investor-ownership (Sun, 2003). Their existence challenge conventional theories based on transaction costs as the sole explanation for governance structure.

Economic history provides a similar challenge to how the JSC is viewed. Initially economic thought focused on the adversarial nature and the constraints faced by the JSC, particularly its implication for transaction costs. A central feature of Adam Smith's writings is his concerns on the problem of disinterested ownership of land and capital. The JSC resulted in a transfer of capital from persons immediately interested in its good condition, to a set of persons, such as creditors of the public, who have no such interest leads in the long run to the possibility of the running down of the capital stock. Smith argued that the proprietors of these companies rarely knew much about the nature of their businesses but were content to receive the dividend. Similarly Marshall (1920) pointed out that at the end of the $19^{\text {th }}$ century, many firms inherited from the industrial revolution, lacked the creative entrepreneurship of their founders and as such tended to stagnate.

Yet the emergence of the JSC also signalled a change in the boundaries of the traditional firm. The beginning of the $20^{\text {th }}$ century witnessed a shift in the concept of property from the physical corporeal and incorporeal property, to intangible property taking the form of a transaction (Commons, 1934). Schumpeter (1928) noted that the transition from competitive to 
"trustified" or regulated capitalism at the beginning of the twentieth century resulted in a shift in the source of entrepreneurship (Schumpeter, 1928). Under competitive capitalism innovation was embodied in the foundation of new firms. Under "trustified capitalism" innovation was instead embodied in large units that already existed and occurred largely independent of individual persons. Schumpeter was critical (1942) of the mainstream economic orthodoxy of the time for failing to realise these creative and destructive features of capitalism. It was this evolutionary process that Schumpeter viewed as the source of largescale enterprises innovation.

The transaction cost approach in associating large firms with shirking and increasing monitoring costs arising out of market failures (e.g. Coase, 1937; Alchian and Demsetz, 1972), therefore only explains part of the evolution of the JSC. Lazonick (1991) criticises the nexus of contracts approach on the grounds that it assumes the pre-existence of markets. The firm is essentially a passive player that arises out of market failure as opposed to organisational success (Lazonick, 1991). The emergence of large firms described in this paper suggests that they were far from passive actors. These adaptive elements within the JSC are better understood with theories that view the firm as collection of investments built around a critical resource (Rajan and Zingales, 1999), or as a collection of growth opportunities (Myres, 1977). The latter approach is particularly relevant for developing economies, where the existence of fully functioning markets cannot be assumed.

\section{Implications for Developing Economies}

The challenge for many developing economies is not unlike that faced by UK and the US in the $18^{\text {th }}$ and $19^{\text {th }}$ centuries. "What had to be found was a way of ensuring the stability of the investment from the industrialist's point of view while enabling the investor, if needs be, to mobilise his investment" (Supple: 1976:261). Developing economies need capital to finance development. Yet, just like the developing financial centres in the UK and the US described in this paper, they often lack the financial institutions and standards of corporate governance present in developed countries that could provide investors with confidence to invest. The experiences of both the UK and US raise an interesting question for developing economies regarding the extent they should follow the JSC model adopted in the UK and US?

It is commonly assumed that the only way for developing countries to converge with western best practice is to privatise and liberalise. Yet the development of governance structures in developed nations has been a much more complex process. In the absence of legal institutions, new property rights tended to be internalised in the firm rather then the market. As 
a consequence, centralised control structures, monopolies and corporate malpractice were common features of early corporate governance. Before active capital markets could develop, a professional management class was required. Liberalisation of many state restrictions often only occurred after economic developments made their existence impractical. Where the costs of market transactions were high, such as in $19^{\text {th }}$ century America, alternative, non-market governance solutions often based on reputation, trust and self-regulation, were necessary to raise finance.

For developing economies, these developments indicate that a more immediate concern may be to put in place the managerial incentives that encourage the adoption of better governance practices. Economic history illustrates the value of developing professional managerial structures through reducing the restrictions on entrepreneurship, even for state enterprises. At the macro level, it illustrates how adapting international financial techniques to domestic conditions, as opposed to the wholesale transplanting and implementation of western standards, can improve the mobilisation of finance. At enterprise level, the history of financial development indicates that enterprises can benefit from the oversight functions of financial intermediaries and international financial markets. However in the absence of enforceable laws or established business norms, these development need to be carefully weighed against the costs attached. The history of the JSC has shown that market crises and the revelation of corrupt practices may be an inevitable part of this process. It should therefore be of little surprise if in the short term state ownership and centralised control structures persist as a best means to limit the expropriation assets. Overall however, the lessons of financial market development indicate that while the development of strong legal and political institutions undoubtedly matter, they are not a precondition for development.

\section{Conclusion}

Although it is difficult to sum up precise conclusions on the many events outlined in this brief history of the JSC, the main implication is that the JSC is not a passive economic actor, but rather an adaptive organisational form. Therefore, although legal and political structures are relevant for explaining governance configurations of JSCs in developed economies, how they are relevant is better understood from a political economy perspective. In the absence of formal codes and regulations, strong corporate interest can gain considerable influence over legal and political institutions and therefore influence the rules of the game. Under such conditions, the paper described the prevalence of unorthodox ownership structures, adaptive behaviour and self-regulation in the development of the Anglo American JSC. It also 
described how legal and political interventions often served to legitimise events in the market place. Legal initiatives often gave an impression of change, when in reality they often merely legitimised changes that had already occurred. Impartial regulation tended to emerge only when corrupt practices became so numerous that they became unsustainable. However, just as codes represented an important means of managing short-term access to resources during the Californian gold rush, the long-term security of property rights is ultimately dependent on strong legal and political institutions.

From an analytical perspective, the historical evolution of the JSC indicates that in order to account for the many changes in that underpinned the emergence of the JSC with limited liability, a more rewarding approach is to focus on the dynamic political economy changes that occur and the factors underpinning their initiation. For developing economies, where many of the institutions of a market economy are either absent or at an early stage of development, this approach has greater explanatory validity. When property rights are unclear, or the legal system can be manipulated, what may matter more is the ability of innovative agents to initiate growth by credibly committing to respect property rights and adopt better governance practices. Identifying these innovations and their limitations requires an approach to analysis that looks beyond the conventional theories of ownership and legal origin. 


\section{Bibliography}

Alchian, A., and H. Demsetz, 1972. "Production, Information Costs, and Economic Organisation" The American Economic Review, Vol. 62(5), pp. 777-795.

Bebchuk, L., 1999. "The rent protection theory of corporate ownership and control" Working paper: Harvard Law School: Cambridge, MA.

Berle, A.A. and G.C. Means, 1932. The Modern Corporation and Private Property, New York: MacMillan.

Chambers, J.D. 1961. The Workshop of the World: British Economic History from 1820 to 1880, London: Oxford University Press

Chandler, A.D., 1977. The Visible Hand: The Managerial Revolution in American Business. Cambridge: Harvard University Press.

Cheffins, B.R., 2000. "Putting Britain on the Roe Map. The Emergence of the Berle-Means Corporation in the United Kingdom, University of Cambridge, February 2000".

Clay, K., and G. Wright, 2005. "Order without Law: Property Rights during the California Gold Rush," Explorations in Economic History, Vol. 42, pp. 155-183.

Coase, R., 1937. “The Nature of the Firm”. Economica, Vol. 4, pp. 386-405.

Cheffins, B.R., 2002. Investor Sentiment and Antitrust Law as Determinant of Corporate Ownership Structure: The Great Merger Wave of 1897 to 1903. University of Cambridge, December 2002.

Coffee, J.C. 1999. "The Future as History: The Prospects for Global Convergence in Corporate Governance Convergence and its Implications" Working Paper, No.144, Centre for Law and Economic Studies, Columbia University School of Law (NY).

Coffee, J.C., 2001. "The Rise of Dispersed Ownership: The Roles of Law and the State in the Separation of Ownership and Control". The Yale Law Journal, Vol. 111 (1) (October), pp. 1-82.

Commons, J.R. 1934. Institutional Economic: Its Place in Political Economy Vol. 1, London, Macmillan.

Davis, L.E., 1965. "The Investment Market, 1870-1914: The Evolution of a National Market", The Journal of Economic History, Vol. 25 (3), pp. 355-399.

Davis, L.E., 1966. "The Capital Markets and Industrial Concentration: The US and UK, a Comparative Study", The Economic History Review, New Series, Vol. 19 (2), pp. 255272.

Dillon, T.H., 1925. “Some Aspects of Utility Regulation,” Harvard Business Review, pp. 3239.

Gerschenkron, A., 1962. Economic Backwardness in Historical Perspective: A Book of Essays, Cambridge: Harvard University Press.

Gille, B., 1976. "Banking and Industrialisation in Europe, 1730-1914," in The Industrial Revolution 1700-1914, The Fontana Economic History of Europe, Volume 3, Cipolla, C.M., Ed, pp. 255-300, Sussex: Harvester Press.

Glaeser, E.L. and A. Shleifer, 2003. “The Rise of the Regulatory State” Journal of Economic Literature, Vol. XLI (June, 2003), pp. 401-425. 
Hansmann, H., 1996. The Ownership of Enterprises. Cambridge, MA: The Belknap Press of Harvard University.

Harris, R., 1994. “The Bubble Act: Its Passage and Its Effects on Business Organisation”, The Journal of Economic History, Vol. 54 (3), pp. 610-627.

Harris, R., 1997. "Political Economy, Interest Groups, Legal Institutions, and the Repeal of the Bubble Act in 1825", The Economic History Review, New Series, Vol. 50 (4), pp. 675-696.

Jones, C., 1993. "The New Opposition in the House of Lords, 1720-1723", The Historical Journal, Vol. 36 (2), pp. 309-329.

La Porta, R., F. Lopez-De Silanes, A. Shleifer and R. Vishny, 2000. "Investor Protection and Corporate Governance”, Journal of Financial Economics, Vol. 58 (1), pp. 3-27.

Landes, D.S., 1965. The Rise of Capitalism, New York: Macmillan.

Landes, D.S., 1999. The Wealth and Poverty of Nations: Why Some Are So Rich and Some So Poor, New York: W.W. Norton and Company.

Lazonick, W., 1991. Business Organization and the Myth of the Market Economy Cambridge: Cambridge University Press.

Levine, R. 1999. "Law, finance, and economic growth," Journal of Financial Intermediation, Vol. 8 (1), pp. 36-67.

Lilley, S., 1976. "Technological Progress and the Industrial Revolution, 1700-1914," in The Industrial Revolution 1700-1914, The Fontana Economic History of Europe, Volume 3, Cipolla, C.M., Ed, pp. 187-244, Sussex: Harvester Press.

Marshall, A., 1920. Principles of Economics, $8^{\text {th }}$ edition, Macmillan: London.

Michie, R.C. 1987. The London and New York Stock Exchanges, 1850-1914, London: Allen and Unwin.

Myres, S., 1977. “Determinants of corporate borrowing," Journal of Financial Economics, Vol. 5, pp. 147-175.

Neal, L., 1987. "The Integration and Efficiency of the London and Amsterdam Stock Markets in the Eighteenth Century" The Journal of Economic History, Vol. 47 (1), pp. 97-115.

Pagano, M. and P. Volpin, 2001. "The Political Economy of Corporate Governance” Working Paper No. 29, Centre for Studies in Economics and Finance, Universita di Salerno, www.unisa.it.

Patterson, M. and D. Reiffen, 1990. "The Effect of the Bubble Act on the Market for Joint Stock Shares", The Journal of Economic History, Vol. 50 (1), pp. 163-171.

Payne, P.L., 1978. "Industrial Revolution and Management in Great Britain," in The Cambridge Economic History of Europe Volume VII, The Industrial Economies: Capital, Labour, and Enterprise (Part 1), Mathias, P., and M.M. Postan, Eds, pp. 180-230, Cambridge: Cambridge University Press.

Pollard, S., 1964. "Fixed Capital in the Industrial Revolution in Britain", The Journal of Economic History, Vol. 24 (3), pp. 299-314.

Pratt, J.A., 1980. "The Petroleum Industry in Transition: Antitrust and the Decline of Monopoly Control in Oil”, The Journal of Economic History, Vol. 40 (4), pp. 815-837. 
Rajan, R. and L. Zingales, 1998. "The Governance of the New Enterprise," Working Paper, The University of Chicago, Graduate School of Business.

Rajan, R. and L. Zingales, 1999. "The firm as a dedicated hierarchy: A theory of the origins and growth of firms." Working Paper, The University of Chicago, Graduate School of Business: http://gsblgz.uchicago.edu.

Rajan, R. and L. Zingales, 2003. "The great reversals: the politics of financial development in the twentieth century," Journal of Financial Economics, Vol. 69, pp. 5-50.

Ramirez, C.D., 1995. “Did J.P. Morgan's Men Add Liquidity? Corporate Investment, Cash Flow, and Financial Structure at the Turn of the Twentieth Century" The Journal of Finance, Vol. 50 (2), pp. 661-678.

Roe, M.J., 2000. "Political Foundations for Separating Ownership from Corporate Control". Stanford Law Review, Vol. 53 (3) (December), pp. 1-67.

Roe, M.J., 2005. "Regulatory Competition in Making Corporate Law in the United States-and its Limits" Oxford Review of Economic Policy, Vol. 21 (2), pp. 232-242.

Seligman, J., 1983. "The Historical Need for a Mandatory Corporate Disclosure System," The Journal of Corporation Law, Vol. 9 (1), pp. 1-61.

Schubert, E.S., 1988. "Innovations, Debts, and Bubbles: International Integration of Financial Markets in Western Europe, 1688-1720", The Journal of Economic History, Vol. 48 (2), The Tasks of Economic History, pp 299-306.

Schumpeter, J., 1928. “The Instability of Capitalism,” The Economic Journal, Vol. 38 (151), pp. 361-386.

Schumpeter, J., 1942. Capitalism, Socialism, and Democracy. New York: Harper.

Smith, Adam, 1778. The Wealth of Nations: Volume 1 (1951 edition), London J.M. Dent \& Sons.

Smith, Adam, 1778. The Wealth of Nations: Volume 2 (1947 edition), London J.M. Dent \& Sons.

Stevens, W.H.S., 1926. "Stockholders' Voting Rights and the Centralization of Voting Control", The Quarterly Journal of Economics, Vol. 40 (3), pp. 353-392.

Supple, B., 1976. "The State and the Industrial Revolution, 1700-1914," in The Industrial Revolution 1700-1914, The Fontana Economic History of Europe, Volume 3, Cipolla, C.M., Ed, pp. 301-353, Sussex: Harvester Press.

Sun, L., 2003. Ownership and Governance of Enterprises: Recent Innovative Developments. London: Palgrave Macmillan Press, 2003.

Sylla, R., 1967. "Finance and Capital in the United States, 1850-1900", The Journal of Economic History, Vol. 27 (4) The Tasks of Economic History, pp. 621-624.

Thompson, E.P. (1967). "Time, Work-Discipline, and Industrial Capitalism", Past and Present, No. 38 (December), pp. 56-97.

Zingales, L., 2000. "In Search of New Foundations", The Center for Research in Security Prices, University of Chicago, Graduate School of Business, Working Paper No. 515. 